\title{
Textual Meanings of the Representation of Intimate Partner Violence by the Kenyan Press
}

\begin{abstract}
This article is a textual analysis of the representation of the political, economic and social contexts of intimate partner violence by the Kenyan press. The article argues that the Kenyan press presents a stereotypical and sensational view of intimate partner violence. Although the violence was overly presented as a problem afflicting women, such coverage was to some degree merited in the face of existing evidence showing that it affects more women than men. However, this coverage should also be reflective of the extent to which the public discourse agrees with such a perspective given similar reports of female perpetrated violence in the country. The article examines the headlines, photographs, captions and cartoons used to represent the contexts of the violence. It also analyses the metaphors, analogies and intertexts in selected stories to thematically unpack their meanings. The representation of intimate partner violence using the textual forms connote the existence of a problematic gendered situation in Kenya. The textual analysis of the representation shows that for intimate partner violence to be alleviated in Kenya, women should be empowered.
\end{abstract}

Charles Wagunda $^{1 *}$ Fredrick Ogenga ${ }^{2}$ John Oluoch ${ }^{3}$

1. School of Information Communication and Media Studies, Rongo University

PO box 238-40404, Rongo, Kenya

2. School of Information Communication and Media Studies, Rongo University

PO box 103-40404, Rongo, Kenya

3. School of Information Communication and Media Studies, Rongo University

PO box 103-40404, Rongo, Kenya

*E-mail of the corresponding author: cwagunda@rongovarsity.ac.ke

Keywords: Representation, intimate partner violence, Kenyan press, text

DOI: $10.7176 / \mathrm{NMMC} / 96-08$

Publication date:June $30^{\text {th }} 2021$

\section{Introduction}

This study begins from the perspective that there is a problematic socio-economic and political context to intimate partner violence (IPV) in Kenya that has attracted the country's press attention. Among the various media that have covered IPV, the mainstream press have remained visibly engaged in reporting the problem. Although the Kenyan press represents the problem in a sensational and stereotypical way, the study recognizes that a skewed representation of male perpetrated violence is unavoidable given the statistical evidence showing that more of the victims are female. That said, the sensationalism is most evident in the news headlines such as" Battle of the sexes" and in pictures that reproduce the "helpless victim" myth.

The study examined the way the Kenyan press represents the IPV, the factors that may influence such representations, and the kind of meanings arising. In particular, the study looks at how the Kenyan press structures the production of knowledge about causality and dynamics of the IPV situation in Kenya. The study argues that the Kenyan press has aligned itself to the "stop violence against women" agenda but in doing so magnifying perpetrators as the drunk strange "beasts" and "monsters" at the epicenter of Kenya's IPV. The press in neoliberal democracies such as Kenya act as a watchdog against social ills, but by their very nature they normally frame events to qualify certain discourses and restrict others and thereby limiting possible ways of understanding "reality." In doing so, the press frames debates to suit certain interests, occasionally compromising on its watchdog role in the society. One common way of framing issues is through stereotypes. The western press is often accused of this travesty (Sutherland et al., 2019). As far as covering IPV is concerned, African media face the same accusations (Owusu-Addo et al 2018). The Kenyan press is to be lauded as a defender of human rights, particularly by focusing on gender equality and women's rights issues. It is while playing this role that the press have extended their responsibility to the coverage of intimate partner violence a problem which is globally regarded as an indicator of gender inequality. Over the years, particularly after the enactment of Kenya's 2010 constitution, there have been positive moves towards alleviating the problem of gender-based violence culminating in the enactment of the Anti-Domestic violence Act, (2015). That being the case however, challenges still remain especially on the question of women's participation in politics where the 
achievement of the two-thirds gender rule still remains a mirage.

\section{Intimate Partner Violence (IPV) in the Global Context}

The Meaning of IPV tends to vary based on the context of investigation (Smith, Bond \& Jeffries, 2019). This is due to the multi-faceted nature of the phenomenon. As a result, there is no single universally acclaimed definition of the phenomenon. Many of the commonly used terms are derived from diverse theoretical perspectives and disciplines. However, one of the most frequently used model for understanding intimate partner violence is the "family violence" framework, which has been developed from the fields of sociology and psychology (García-Moreno \& Amin, 2016). Accordingly, "Family violence" refers to all forms of abuse within the family regardless of the age or sex of the victim or the perpetrator. Agarwal, (2018) further notes that there is increasing international consensus that the abuse of women and girls, regardless of where it occurs, should be considered as "gender-based violence," as it largely stems from women's subordinate status in society with regard to men. This definition of IPV recognizes that violence is gendered. Taking this approach is not designed to diminish men's experience of violence since there is evidence that men also experience IPV. The main perpetrators of gender-based violence (GBV) are the youthful males aged 18-33 years who are in a family and/or intimate partner relationship context (National Crime Research Centre [NCRC], 2020). Victims of GBV are majorly girls, women and children (NCRC, 2020). Such statistics bring into focus, the United Nations' (UN) sustainable development goal (SDG) number five which aims at achieving gender equality and empower all women and girls (Leach, 2015). Today, gender inequalities persist thereby stagnating social progress (Kim, 2017). The UN sees elimination of all forms of IPV in the public and private spheres as an effort to build a sustainable future where women are empowered and social progress is encouraged. The presence of intimate partner violence is therefore regarded as a measure of inequality.

\section{Intimate Partner Violence in Kenya}

In Kenya, the terms domestic violence and intimate partner violence are often used interchangeably. Collectively, they refer to a range of behaviours that are violent, threatening, and coercive or controlling that occur within current or past family or intimate relationships (NCRC, 2020).

Kenya's Protection against Domestic Violence Act (2015), defines IPV as abuse that encompasses: child marriage, female genital mutilation, forced marriage, forced wife inheritance, interference from in-laws, sexual violence within a marriage, virginity testing; and widow inheritance, damage to property, defilement, preventing someone from accessing a reasonable share of the facilities associated with the person's place of residence, economic abuse, emotional or psychological abuse, forced entry into the complainant's residence where the parties do not share a residence, harassment, incest, intimidation, physical abuse, stalking, verbal abuse or any other conduct against a person which harms or may cause harm to the safety, health, or well-being of the person. Evidently, this definition is broad-based. However, for the purposes of this study and to take care of the overlap between gender based-violence and domestic violence, the term 'intimate partner violence' was adopted to refer to the range of sexually, psychologically and physically coercive acts used against adults and adolescents by current or former intimate partners.

Kenya has been at the fore front in efforts to eliminate all forms of gender based violence especially since the promulgation of the Constitution of Kenya, (2010) which in article 2(5) and (6) provides that the general rules of international law as well as any, treaty or convention ratified by Kenya form part of the laws of Kenya. All international and regional legislative and policy frameworks adopted and ratified by Kenya have become part of the domesticated laws to fight (GBV). Within this context, Kenya has taken steps in ratifying international treaties and regional conventions on elimination of Sexual Gender Based Violence (SGBV) and gender inequality. She has also put in place a national policy and legislative framework that supports the campaign against all forms of GBV in practice.

The constitution provides that every person has right to freedom and security of their person; this includes the right not to be subject to any form of violence from either public or private sources, any form of torture whether physical or psychological or cruel, inhuman or degrading treatment. The right to security means that the constitution safeguards women's right against SGBV and any other related forms of gender-based violence. Other pieces of legislation with derivative safeguards include: Prohibition of Female Genital Mutilation Act, (2011) which prohibits the practice of female genital mutilation and safeguards against violation of a person's mental or physical integrity. Additionally, The Land Act, (2012) secures rights of women to matrimonial property while Matrimonial Property Act, (2013) provides for the rights and responsibilities of spouses in relation to matrimonial property. The Marriage Act, (2014) provides for the minimum age in marriage and types of marriages. The Act guarantees parties to a marriage, equal rights at the time of the marriage, during the marriage 
and at the dissolution of the marriage. The Protection against Domestic Violence Act, 2015 provides for the protection and relief of members of a family from domestic violence. Given these provisions and the potential influence media have on public understanding of IPV, it is important to then illuminate the nexus between the media and coverage of IPV.

\section{Media Coverage of Intimate Partner Violence}

IPV is a social problem that has captured media attention in Kenya. A study by the National Crime Research Centre [NCRC], (2020) for instance established that $71.0 \%(1,716)$ of the 2,416 cases of GBV cases reported between January and June, 2020 were female victims, that is, 10 females daily (NCRC, 2020). Media coverage of social issues such as IPV therefore plays an important role in shaping and reflecting public opinion (Lloyd \& Ramon, 2017). Research indicates that the media have the ability to mobilize and tap into people's views on social, cultural and political issues (Freedman, 2014; Ray, 2011). Although audiences decide for themselves which papers to read, the content and tone of news coverage are determined by journalists, editors and in some cases media owners (Easteal, Holland \& Judd, 2015). One of the strategies of studying media coverage of IPV therefore, is to examine how media contents challenge cultural and social norms that condone, tolerate or excuse the problem.

In Kenya therefore, the media are expected to work closely with County, national and international partners as well as other relevant stakeholders in the fight against intimate partner violence. The County Government Sexual Gender-Based Violence policy of 2017 for instance envisages the media as actors mandated to provide information, give analyses on enforcement of sexual and gender based violence (SGBV) policies and legislation. At the same time, the media are expected to provide a platform for awareness raising and education for all stakeholders to communicate concerns and opinions (National Gender and Equality Commission [NGEC], 2017)

The existence and nature of IPV in the country is documented in among others, media reports and official records by organizations such as National Crime Research Centre and the National Police service. In 2018 for example, a total of 148 cases of domestic violence cases were recorded by the National Police Service. Such reports have shown that the victims are mostly women although incidents of men's victimization are also reported (National Police Service [NPS], 2018). Even then, IPV is a social problem with various predicators. A study by Aelmans, (2011) for instance identified certain factors to be associated with the experience of intimate partner violence in the country. They include difference in gender role expectations, gender role attitudes, use of passive coping styles, and childhood trauma as well as partner substance abuse. Since the news media serve as a vital channel for public information, as well as a way in which social norms are reflected and reinforced, examining media coverage is an ideal access point for discussions surrounding IPV.

Scholars including Lloyd and Ramon (2017); Morgan and Simons (2018); Sutherland, G., McCormack, A., Pikris, J., Easteal, P., Holland, K., Vaughan, C. (2015); Breen, M., Easteal, P., Sutherland, K., Vaughan, C. (2017); Sutherland, G., McCormack, A., Easteal, P., Holland, K., Pirkis, J. (2016) have made the link between news media descriptions and the public's knowledge and attitudes surrounding IPV. Whereas such previous international researches from mainly western countries highlight that media often normalize IPV by presenting it as routine, Findings on the African continent like Owusu- Addo et al., (2018) show fairly similar patterns indicating for instance that Ghana's media framing of IPV is episodic in nature with depictions of the violence as isolated.

Whereas the choice of media for this study were newspapers, it is important to highlight that there has been some debate in the academia about the extent to which recent developments in information and communication technologies (ICTs) have led to a decline in readership in some cases. Pattabhiramaiah, Sriram and Sridhar, (2018) observe that the command of the traditional newspaper is perceived to have been undermined by alternative online news sources. Such sources include blogs, social media, and free internet content. While this could partly be true, it may not automatically mean that print media no longer play a crucial role in shaping public opinion. As a matter of fact, many reports printed by newspapers are the same reports published online (recognizing that online reports are published more quickly and with an increased ability for modification). In Kenya, there is evidence that audiences find newspaper reporting more credible and trustworthy than other providers (Media Council of Kenya, 2020).

As components of the media therefore, newspapers are key actors in shaping the public discourse. This is because they report on current events and provide a framework for their interpretation. This means that who or what is selected to appear in the news and how those individuals and events are portrayed can have a profound influence on people's attitudes, beliefs, and behavior (Morgan \& Simons, 2018). Given this context' this study 
explored the representation of intimate partner violence by The Daily Nation, The Standard and The Star being among the leading newspapers in Kenya by readership as shown in the next section.

\section{Statement of the Problem}

In Kenya, newspaper reports constitute one of the spaces where the prevalence of IPV is documented. However, past studies have faulted mainstream media- including newspapers- for normalizing IPV through stereotypical and sensationalist reporting. Whereas such reporting is problematic, it is happening at a time when the problem of IPV has captured national discourses. In the year 2020 for example, reports of escalating cases of genderbased violence following the outbreak of Covid-19 led President Uhuru Kenyatta to call for a probe to inform the individual, family and institutional responses to the problem. Even then, prior to Covid-19, Kenya was already experiencing gender based violence with four out of 10 women in Kenya experiencing physical or sexual violence at the hands of a spouse or intimate partner and often this is tolerated and normalized (National Crime Research Centre [NCRC], 2020). A review of past studies on newspaper representation of IPV revealed that the studies have been conducted mainly in the west and not in Kenya, with a prime focus on textual analyses without looking at factors that may account for the representation. This study sought to not only address the dearth of literature on IPV representation in Kenya but also to bridge the knowledge gap by exploring factors that could account for the representation of IPV by the Daily Nation, The Standard and The Star and to unpack the meanings emerging from such representations.

\section{Objectives of the Study}

The specific objectives were:

1. To explore ways in which the mainstream Kenyan newspapers represented intimate partner violence.

2. To determine meanings that emerged from such representations.

\section{Research Methodology}

Based on political economy of the media and cultural studies theories, this study was used a triangulated approach that employed multiple methods (Creswell \& Clark, 2017). The two primary methodologies in the study were quantitative and qualitative content analysis. Using quantitative content analysis method, the frequency of occurrence of various units of analysis related to the social, economic, and political dimensions of texts were counted. Such counting set the foundation for the qualitative analysis. Qualitative content analysis, which involved semiotics and ideological analysis, was used in the study and predominantly so because research on representation of reality by the media is qualitative by nature (Bertrand and Hughes, 2017). The textual elements and narrative genres evident in the selected stories and their frequency of occurrence were analyzed to thematically unpack their meanings.

A total of 98 newspaper editions of the Daily Nation, The Standard, and The Star in Kenya were analyzed. The editions included samples of the three newspapers selected through stratified sampling (constructed weeks) between the years 2014 and 2020. The selected newspapers utilized certain textual devices and narrative genres as techniques of constructing stories about IPV debates in Parliament (politics), economic constraints, and social turmoil in Kenya. The textual devices utilized were in the form of headlines, analogies, metaphors, and intertexts, while narrative genres included photographs and cartoons. The time frame used to select news stories were based on the fact that the critical elements of IPV occurred between 2014 and 2020 and that they were tied to Political debates, economic constraints and social turmoil. The Political debates were tied to IPV laws while social turmoil was tied to Covid-19. The economic constraints were not tied to a particular event. The dimensions cited received considerable coverage in the three newspapers in the period under review.

\section{Results and Discussion}

\subsection{Parliamentary Debates and the Representation of Intimate Partner Violence}

Stories related to debates on the passage of Anti-domestic violence bill in Kenya were chosen from The Daily Nation, The Standard and The Star. In the year 2014, 18 stories were selected: nine were drawn from The Daily Nation, six from The Standard and two from The Star. On June 5, 2014, The Star reported, "House to debate bill on domestic violence-MP". In the article, the bill as a theme was mentioned six times. This was followed by another article by the same paper on July 23, 2014 which was titled "NGOs want tough bill on domestic violence". This particular article themed the bill 13 times. The Star had another article on July 24, 2014 which read, "Women MPs, rights groups call for tougher laws against domestic violence" the bill was mentioned five times. In The Daily Nation, "Lobbies reject bid to weaken violence Bill" was published on August 03, 2014. "Anti-domestic violence Bill was mentioned 10 times. Another article, "Bill triggers battle of sexes in House" was published on August 20, 2014. Therein the countable dimension "bill" was mentioned 21 times. 
The Standard also had, "Domestic violence bill ignites battle of the sexes in House" on August 21, 2014). Antidomestic violence Bill as a countable theme was mentioned 13 times. The Standard commentary which read, 'MPs trivializing debate about the family and domestic violence' was published on August 24, 2014. It mentioned the bill 9 times. This was followed by The Daily Nation's, "Women MPs are doing a good job, but battle for gender equity is far from won" on November 10, 2014 where "anti-domestic violence bill was mentioned 11 times. An article published in the Daily Nation on December 13, 2014 mentioned the countable dimension six times. It was titled, "Report reveals 'extensive' violence against women" on December 13, 2014. Other articles included The Standard's March 5, 2015 publication which said, "With five new laws to protect women, why is gender violence still prevalent?" it mention the domestic violence bill twice. On February 15, 2016 The Star reported, "Domestic violence law explained; police no longer require a warrant to arrest suspect". It mentioned the bill four times. Lastly, The Standard had another opinion piece headlined, "Parliament a letdown to war on gender violence" on December 12, 2019 and here, the bill was referred to three times. President Uhuru Kenyatta issues directives on increased cases of gender-based violence" Msitsa (2020)

\subsection{The Economic Constraints and the Representation of Intimate Partner Violence}

A total of 25 stories were selected in relation to economic aspects of IPV in Kenya; 9 from The Daily Nation, 2 from The Star and two from The Standard.

A title in the Daily Nation published on July 2, 2020 read, "Covid-19 spotlights discrimination women face" (Mwololo, 2020). It mentioned the countable economic dimension 11 times. It was accompanied by a photograph of women working in a textile processing plant. Another article on August 7, 2016, read: "Financial dependence confines women to abusive marriages". The expression "financial dependence" appeared once. It was accompanied by a photograph of Jackline Mwende in bandages. She was a victim of domestic violence whose hands had been chopped off by her husband in Machakos. Another article on November 25, 2019. It read: "Domestic violence costs Kenyan economy Sh5 billion annually". The expression cost of violence appeared thrice similar to "economy" which also appeared three times. It was accompanied by the figure of a man with raised hands ready to strike a female figure. The same report appeared in The Star which wrote, "Domestic violence robs Kenya's economy Sh5bn annually-KPMG" on October 26, 2019. In the article, "economy" appeared twice. On 4th December, 2019, the Daily Nation, had an article titled: "Domestic violence costly to global economy, report says"

An article in the Daily Nation on May 22, 2020 read, "GBV rise will slow recovery of global economy, UN Women" The word "economy/ economic appeared 10 times. It was also accompanied by the picture of a man with raised hands ready to hit a cowering woman. On October 21, 2020 in the life-and-style segment, a story titled, "Spare a thought for rural woman burdened by unpaid care, chores" was published. The expression "unpaid care" which referred to an economic question and the word "economic" appeared once in each case.

"Nairobi's slum women bear the brunt of domestic violence" was also published by Daily Nation on October 22, 2020. The economic aspect counted was the reference to "slum" which was mentioned five times. It was accompanied by an aerial photograph of a section of Kibera slums.

“Abolish P3 form charges for GBV cases, plead women" December 18, 2020 was another title. It mentioned the term charges/charged four times. It was accompanied by a picture of activists and civil society members mark the 16 Days of Activism against Gender-based Violence in Isiolo. An almost similar headline in The Star read, "Domestic violence on the rise in Nairobi's low income areas-report" on October 13, 2020. It had the term "income" twice and an equal number for "economy" Others included, "Kangata seeks zero rated cost of justice for GBV victims" was a headline that appeared on December 15, 2020 in the Daily Nation. "Cost of justice" as a countable theme was mentioned three times. In The Standard, an IPV story titled, "Paying family bills saves women from beatings-study" appeared on January, 19 2019. "Household expenses" as accountable expression occurred five times As well as "Violence against women and the link to the economy "(Mboga, 2020). "Cost of violence" was mentioned 10 times.

\subsection{Covid-19 and the Representation of Intimate Partner Violence}

The representation of social disruptions was finally examined under Covid-19. They were 55 in number. Such articles were mainly published in 2020 following the outbreak of the novel corona virus. Headlines that were analysed in the Daily Nation included an article on December 9, 2020. It read, "Covid-19 has fanned cases of GBV, report shows" Maichuhie (2020). The countable dimension, "Covid-19" was mentioned twice. "Covid-19 spotlights discrimination women face" (Mwololo, 2020). It was published on July 2, 2020 and it mentioned the dimension 19 times. It was accompanied by a photograph of women working in a textile processing plant. "Covid-19 offers chance to examine existing gender biases" Odumbe (2020) was another article on July 8, 2020. 
The Covid-19 dimension was mentioned 11 times. "Violence against women as global as Covid-19 crisis" Donovan (2020) mentioned the countable theme eight times. It also focused on economic hardships women face. On May 19, 2020, the Daily Nation published, "Virus portends economic catastrophe for women" (Andago, 2020). The countable theme appeared eight times. It was accompanied by a picture of women hawking bottled water in Nairobi. "Covid-19 aggravating gender inequalities" Obiria (2020) was published on March 30. The accompanying picture of a woman in an open air market was captioned, "A woman sells oranges at Nairobi Bus Station during rush hour before Covid-19. Such businesses have been adversely affected by the pandemic." "Speak out on sexual and gender violence amid coronavirus fight" Rugene, (2020).there were 13 mentions of Covid -19. It was accompanied by the picture of a cowering woman with a hidden face and a raised arm depicting the "stop' sign. It also mentioned economic hardships thrice. "Women in slums at risk as violence cases spike" Chege and Kahenda (2020) was published by The Standard on November 26. It had two photographs. The first was captioned, "Mombasa women and human right groups march from Sabasaba to Lights as they commemorated International Women's day in Mombasa County on Friday March 8, 2019”. The second photograph pictured Haki Africa's Salma Hemed demonstrating physical injuries from a battered woman during the celebration of the International Women's day in Mombasa County on Friday March 8, 2019. It mentioned the virus four times. "Domestic violence on the rise amid pandemic "was also published by The Standard on April 14, 2020. It was accompanied by the drawing of a female head with the stop sign inscribed and it mentioned the pandemic three times. In the same newspaper, "Job losses and violence top list of Covid-19 impact" Onyango, (2020) mentioned the virus nine times. It also focused on the economic dimensions three times. "Domestic conflict surges as corona takes heavy toll on many families" Adhiambo and Kanja (2020) was published on July 7. It mentioned the virus five times while financial theme was mentioned once. "We're a family; let's stop our fights and focus on surviving coronavirus" Oginde (2020) was published on April 26. It mentioned the virus four times. "Don't allow virus to expose women to rights abuses" Ong'ang'a (2020) mentioned the countable theme four times.

In The Star, the titles comprised, “Kagwe: Don't take virus stress out on spouses, children” Cheruiyot, (2020), "Women hold on to abusive marriages" Mkongo, (2020) which explained that curfew and stay-at-home directives have stirred tensions in homes. Another article,"Covid-19 woes: Domestic violence on the rise" Kamau, (2020) pointed out family break-ups, sexual and physical abuse aspects of IPV. "Women need extra protection during, after pandemic" Mbugua, (2020) detailed how more infections would lead to increased burdens on women and vulnerability to domestic violence. Another article, "Provide support to girls, women during Covid-19 pandemic" Nthiana, (2020) expressed the need to consult female adolescents to understand their concerns, fears and needs. "Domestic violence, sexual attack cases on the rise-Gender commission" Otenyo (2020) indicated that violence was mainly directed at women and girls. "Why Covid-19 will hit women harder" Mbugua, (2020) noted that women often faced the choice of giving up paid work to care for children at home.

In The Standard, "Domestic violence on the rise amid pandemic" Masiga, (2020) was an opinion article which reported that 56 more cases had been reported in January alone. It was accompanied by the drawing of a female head, inscribed with the stop sign, implying that such violence was against females. "Women in slums at risk as violence cases spike" Chege and Kahenda, (2020) was accompanied by two pictures, one being of women demonstrating in a Mombasa street and another one showing a "Haki Africa" official demonstrating injuries from a battered woman during the celebration of the International Women's day in Mombasa County on Friday March 8, 2019. We're family; let's stop our fights and focus on surviving coronavirus Oginde, (2020) focused on the impact that domestic violence had on small children. "Sex predators on the rampage amid curfew" Mungai, (2020) was published on April 18 by The Standard. Curfew was counted once while coronavirus was counted three times. The last article that was selected under this segment was an opinion piece was titled, "Don't allow virus to expose women to rights abuses" Onganga, (2020) was published on November 14. It mentioned Covid19 four times. "Women hold on to marriage despite abuse in lockdown" was published on June 12, 2020. It was accompanied by a drawing of a woman's bloodied face being strangled by a man's muscled hand. Countable dimension "lockdown appeared three times while covid-19 appeared six times. In all, newspaper stories in this category represented the negative impacts of Covid -19, but mainly as related to women and girls.

\subsection{Representation through Textual Analysis}

The analysis in this section centred on the textual genres and narrative devices utilised in representing the IPV. Textual genres focused on headlines, photographs, captions and cartoons while narrative devices paid attention to metaphors in selected stories. The analysis showed how the newspapers constructed the discourse of fighting IPV through a "stop violence against women" philosophy. The newspaper discourse showcased prescriptive measures of stemming IPV by essentially underscoring the need to empower women as a way of addressing the problem. In doing so, the selected newspapers employed textual devices and narrative genres to represent the 
IPV problem. There were no metaphors depicting economic hardships.

\subsection{Representation of IPV Law Debates through Textual and Narrative Forms}

The analysis of the headlines showed that that political IPV debates were represented as male versus female duels. They included headlines such as, 'Women MPs are doing a good job, but battle for gender equity is far from won' Kweyu, (2014), the arguments in the article showed polarized debates in support of and opposition against IPV legislation for example,

Female legislators, most of whom are in Parliament because of the Constitution's affirmative action provisions, are pushing through Bills of great import to women and children, bringing the erstwhile missing feminine touch to a predominantly masculine legislature. Within 20 months of joining Parliament, the women are overcoming opposition from their male colleagues, whose patriarchal mindset saw the Marriage Bill, for instance, gather dust for decades (Kweyu, 2014).

Another headline, 'Bill triggers battle of sexes in House' Wafula, (2014) reported, 'Debate on the Protection against Domestic Violence Bill turned into a battle of sexes pitting female MPs against their male counterparts.' Some male MPs reportedly argued that, "Parliament cannot legislate on bedroom affairs and love matters." The Majority Leader, while opposing the Bill at that time also disputed inclusion of economic abuse in the Bill, saying, "it cannot be defined as domestic violence". He also disputed the definition of violence as emotional abuse saying, "Mr. Speaker, we don't want to create laws to manage our bedrooms and sitting rooms. We have more serious issues to deal with like terrorism, food insecurity, and devolved system". The excerpt indicated not only how the political debates were viewed through a male versus female lens but also how political debates trivialized IPV. The issue of trivializing IPV was depicted in another title which read, 'MPs trivializing debate about the family and domestic violence' Thongori, (2014) its lead sentence said,

Once again Members of Parliament have been divided into men and women camps. It is curious that on all matters except family-related issues, lawmakers take positions depending on their party affiliations. When it comes to family-related Bills, however, they vote as men and women (Thongori, 2014).

Table 1. Political debates: Forms of Textual and Narrative Representation and Frequency of Occurrence

\begin{tabular}{|l|l|l|}
\hline Forms of representation & Reference to IPV laws & Percentage \\
\hline Headlines & 18 & 62.07 \\
\hline Photographs and captions & 4 & 13.79 \\
\hline Metaphors & 7 & 24.14 \\
\hline Total & $\mathbf{2 9}$ & $\mathbf{1 0 0}$ \\
\hline
\end{tabular}

In another instance, male members of Parliament were reported to have shocked their women colleagues over Domestic Violence Bill. This was in an article titled, "Domestic violence bill ignites battle of the sexes in House" (Shiundu, (2014).

Other headlines included, 'Lobbies reject bid to weaken violence Bill', Muiruri, (2014), in which male legislators were depicted as keen on diluting the contents of the proposed anti-violence bill and "Parliament a letdown to war on gender violence" Ogutu, (2019).

Metaphors in IPV Law Debates

The IPV law debates were styled as "battle of the sexes" The battle of the sexes narrative was mainly seen through the lens of difficulties that female legislators faced in pushing through laws that were aimed at addressing the IPV problem. An example was found in The Standard on $5^{\text {th }}$ March, 2015 in which a female parliamentarian was quoted,

But while the laws might be good for women, the battle to make the men in Parliament understand this is Herculean. Notably, there are only 68 women in the National Assembly out of a total membership of 350, and 18 women in the Senate out of 68 senators.

Beatrice Elachi, the most senior woman in the Senate hierarchy - Chief Whip of the Majority Party - told The Standard that while laws exist, women lawmakers must flex their muscle and raise their voices more for their issues to be heard.

"We have to fight for the political space and platform to get women's issues addressed. In a Senate where all elected senators are men, and some of them are former Cabinet ministers, it does take courage. We really fight!" said Ms. Elachi, a nominated senator.

Other instances which may already have been pointed out included, 'Women MPs are doing a good job, but battle for gender equity is far from won' Kweyu, (2014), Bill triggers battle of sexes in House' Wafula, (2014) 
IPV Law Debates in Pictures and Captions

The main photograph used in 2 articles depicted a parliamentary session. One of the photographs was captioned, "The National Assembly in session. Debate on the Protection Against Domestic Violence Bill turned into a battle of sexes pitting female MPs against their male counterparts". A similar picture was used in The Daily Nation's article, "Women MPs are doing a good job, but battle for gender equity is far from won". This was on November 10, 2014. It was captioned, "A joint National Assembly and senate sitting on March 27, 2014. Debate on how to satisfy the one-third gender rule has taken centre-stage with some senators and experts saying that 80 of the 290 seats in the National Assembly be dedicated to women". From the pictures, it was apparent that Kenya's legislature was male dominated. The analysis of the headlines showed representation as masculinized, individualized and trivialized in male dominated legislative debates.

\subsection{Representation of Economic Problems through Textual and Narrative Forms}

Economic problems was the second chosen theme. The textual analysis of the three selected newspapers presented the economic plight of women either due to their dependence on men or due to loss of livelihood as a result of social disruptions in the society. The analysis therefore showed that the articles advanced the ideology that alleviation of IPV facing women lay in their economic empowerment or independence. These positions were represented through a range of textual and narrative forms.

Table 2: Representation of Economic problems through Textual and Narrative Genres

\begin{tabular}{|l|l|l|}
\hline Forms of Representation & Number of References & Percentage \\
\hline Headlines & 25 & 58.14 \\
\hline Photographs and Captions & 15 & 34.88 \\
\hline Metaphors & 3 & 6.98 \\
\hline Total & $\mathbf{4 3}$ & $\mathbf{1 0 0}$ \\
\hline
\end{tabular}

The table shows the major ways of representation of economic aspects of IPV were headlines, photographs and captions and as depicted in table 2. Metaphors were only minimally used.

A number of headlines $(n=25)$ suggested that the economic problems associated with IPV, particularly violence against women, had led to the suffering of Kenya's economy and that female victims of IPV stayed in abusive relationships because of economic dependence on men. Headlines such as "The ugly face of domestic violence" Omboki, (2016) metaphorically represented the costly nature of treating an IPV victim at the average of Sh56, 000 for a single case of gender-based violence whilst also revealing that some victims got P3 Forms, not with the intention of pressing charges against the aggressors, but instead use them to blackmail the offenders to compensate them, usually in the form of a few animals or cash. It was accompanied by a photograph that was captioned, "The recent increase in gender-based violence cases in Kisii and Nyamira counties has prompted a small but active group to take action to ensure the culprits are punished"

The photograph accompanying the article showed a woman cowering under a towering male figure apparently ready to strike her. In this very article, IPV was metaphorically referred to as "epidemic of violence" and in one instance, an anti-IPV activist was quoted as saying, "the vice had reached epidemic levels" to mean it had become pervasive in the society. In another case, a headline, "Gender based violence on increase, State urged to protect victims" Rugene, (2020) indicated the need for action by the government. Such is the action that was taken by President Uhuru Kenyatta whose directive to the National Crime Research Centre to carry out research to inform measures that the government would undertake to alleviate the problem led to a report titled, "Protecting the Family in the Time of Covid-19: Addressing the Escalating Cases of Gender Based Violence, Girl Child Disempowerment and Violation of Children Rights in Kenya". Women's economic activities were easily represented through photographs that depicted them performing various chores such as the article in the Daily Nation on May 22, 2020 which read, "GBV rise will slow recovery of global economy, UN Women" and accompanied by a photograph captioned as "Women at Mbudzi Village in Jaribu, Kilifi County, mining iron ore to feed and educate their families. As Covid-19 takes a toll on the world, UN Women says it will push women into more poverty

An article titled, "Spare a thought for rural woman burdened by unpaid care, chores" published on October 21, 2020 , by the Daily Nation was accompanied by a photograph of two women doing farm work. It captioned women working in a rice paddy in West Kano irrigation Scheme in Kisumu County.

Another way in which economic elements were represented was through photographs of poor neighbourhoods 
where cases of IPV were reportedly higher. The Star had a case in point in which the article headed "Domestic violence on the rise in Nairobi's low-income areas - report" Vidija, (2020) was accompanied by a photograph of Kibera slums in Nairobi where cases of IPV have been reported by the media. In analyzing the economic representation, it was apparent that newspaper coverage focused on the hardships that women faced and hence, fashioned IPV mitigation only through the lens of women's economic emancipation.

\subsection{Representation of Social turmoil through Textual and Narrative Forms}

Table 3 shows that headlines, photographs and captions dominated the social turmoil representation.

Table 3: Representation of social turmoil through Textual and Narrative Genres

\begin{tabular}{|l|l|l|}
\hline Forms of Representation & Number of References & Percentage \\
\hline Headlines & 55 & 44 \\
\hline Metaphors & 15 & 12 \\
\hline Intertexts & 3 & 2.4 \\
\hline Photographs and Captions & 45 & 36 \\
\hline Cartoons & 7 & 5.6 \\
\hline Total & $\mathbf{1 2 5}$ & $\mathbf{1 0 0}$ \\
\hline
\end{tabular}

In 45 cases, the photographs accompanying the main story were mainly scenes depicting a man beating a defenseless woman. Metaphors compared men with animals by calling the perpetrators "beasts" and "monsters" for example The Star on May 232020 story titled, "Gender violence: Kenya's growing shadow epidemic" Muchangi, (2020) had a cartoon of a cowering girl under a gigantic arm ready to grab her. Such representations emphasized perpetrators as 'others' and themed the "helpless victim syndrome"

\subsection{Conclusion}

The textual devices and narrative genres used by the Daily Nation, The Standard, and The Star to represent IPV in Kenya are characterized by trivialization by personalized discourses and sensationalism through "othering". Their coverage of the problem suggests that IPV is a problem afflicting "helpless women" what Johnson, (2020) refers to as "the battered woman syndrome" In particular, the problem is attributed to the "beast" or "monster" who pounces on a defenseless spouse. There is therefore a common thread that skews the representation as a woman's problem and distances it from the ordinary man. The argument from the semiotic analysis of texts and narratives used to represent the situation is, "Empower women" to stop IPV in Kenya. Based on the press coverage of IPV, the study finds that the political debates in Kenya are still dominated by the male-female divide where male domination reigns and that such dominance was reflected in the trivialization of IPV by male law makers. Furthermore, social disruptions such as Covid-19 essentially captured the women's plight with limited references to female perpetrated IPV. The study could have possibly benefited from the inclusion of more publications and as such, the limited number of editions under review means the findings of this study cannot be overgeneralized.

\subsection{References}

Aelmans, M. (2011). Predictors of intimate-partner violence experienced by female staff and outpatients at MTRH in Eldoret, Kenya (Master's thesis). Moi University, Eldoret, Kenya.

Agarwal, B. (2018). Gender equality, food security and the sustainable development goals. Current opinion in environmental sustainability, 34, 26-32.

Bergenfeld, I., Lanzas, G., Trang, Q. T., Sales, J., \& Yount, K. M. (2020). Rape myths among university men and women in Vietnam: a qualitative study. Journal of interpersonal violence, 0886260520928644.

Bertrand, I., \& Hughes, P. (2017). Media research methods: Audiences, institutions, texts. Macmillan International Higher Education.

Breen, M. D., Easteal, P., Holland, K., Sutherland, G., \& Vaughan, C. (2017). Exploring Australian journalism discursive practices in reporting rape: The pitiful predator and the silent victim. Discourse \& Communication, 11(3), 241-258.

Creswell, J. W., \& Clark, V. L. P. (2017). Designing and conducting mixed methods research. Thousand Oaks, Sage publications.

Easteal, P., Holland, K., \& Judd, K. (2015, January). Enduring themes and silences in media portrayals of violence against women. In Women's Studies International Forum (Vol. 48, pp. 103-113). Pergamon.

Freedman, D. (2014). The contradictions of media power. London, Bloomsbury.

García-Moreno, C., \& Amin, A. (2016). The sustainable development goals, violence and women's and children's health. Bulletin of the World Health Organization, 94(5), 396.

Johnson, M. P. (2017). Patriarchal terrorism and common couple violence: Two forms of violence against 
women (pp. 3-14). Routledge.

Kim, E. M. (2017). Gender and the sustainable development goals. Global Social Policy, 17(2), 239-244. Leach, M. (Ed.). (2015). Gender equality and sustainable development. Abingdon, Routledge.

Lloyd, M., \& Ramon, S. (2017). Smoke and mirrors: UK newspaper representations of intimate partner domestic violence. Violence against women, 23(1), 114-139.

Media Council of Kenya. (2019). Status of Media in Kenya Survey Report. Nairobi, MCK.

Morgan, J., \& Simons, M. (2018). Changing media coverage of violence against women: the role of individual cases and individual journalists. Journalism Practice, 12(9), 1165-1182.

National Crime Research Centre (2020). Protecting the family in the time of covid-19 pandemic: addressing the escalating cases of gender based violence, girl child disempowerment and violation of children rights in Kenya. Nairobi: NCRC.

National Gender and Equality Commission (2017). County government policy on sexual and gender based violence 2017. Retrieved from https://www.ngeckenya.org/Downloads/NGEC\%20Model $\% 20$ Policy $\% 20$ GBV\%20for $\% 20$ County $\% 20$ Govt $\underline{\text { s.pdf }}$

National Police Service (2018). Annual crime report 2018. Retrieved from http://www.nationalpolice.go.ke/crime-statistics.html

Owusu-Addo, E., Owusu-Addo, S. B., Antoh, E. F., Sarpong, Y. A., Obeng-Okrah, K., \& Annan, G. K. (2018). Ghanaian media coverage of violence against women and girls: implications for health promotion. BMC women's health, 18(1), 129.

Pattabhiramaiah, A., Sriram, S., \& Sridhar, S. (2018). Rising prices under declining preferences: The case of the US print newspaper industry. Marketing Science, 37(1), 97-122.

Government of Kenya (2015). Protection Against Domestic Violence act no. 2 of 2015. National Council for Law Reporting.

Ray, L. (2011). Violence and society. London, England: Sage

Smith, A. L., Bond, C. E., \& Jeffries, S. (2019). Media discourses of intimate partner violence in Queensland newspapers. Journal of sociology, 55(3), 571-586.

Sutherland, G., Easteal, P., Holland, K., \& Vaughan, C. (2019). Mediated representations of violence against women in the mainstream news in Australia. BMC public health, 19(1), 1-8.

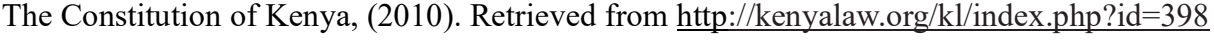

The Land Act, (2012). Retrieved from http://www.parliament.go.ke/sites/default/files/2017-05/LandAct2012.pdf

The Marriage Act, (2014). Retrieved from http://kenyalaw.org/kl/fileadmin/pdfdownloads/Acts/TheMarriage_Act2014.pdf

The Matrimonial Property Act, (2013). Retrieved from https://www.ilo.org/dyn/natlex/docs/ELECTRONIC/97351/115471/F-540095358/KEN97351.pdf 